University of Rhode Island

DigitalCommons@URI

Open Access Master's Theses

1967

\title{
A Comparative Study of the Social Interaction of Advantaged and Disadvantaged Pre-School Children
}

Phyllis Killam Abell

University of Rhode Island

Follow this and additional works at: https://digitalcommons.uri.edu/theses

\section{Recommended Citation}

Abell, Phyllis Killam, "A Comparative Study of the Social Interaction of Advantaged and Disadvantaged

Pre-School Children" (1967). Open Access Master's Theses. Paper 805.

https://digitalcommons.uri.edu/theses/805

This Thesis is brought to you for free and open access by DigitalCommons@URI. It has been accepted for inclusion in Open Access Master's Theses by an authorized administrator of DigitalCommons@URI. For more information, please contact digitalcommons-group@uri.edu. 
A COMPARATIVE STUDY OF THE SOCIAL INTERACTION

OF ADVANTAGED AND DISADVANTAGED PRE-SCHOOL CHILDREN

BY

PHYLLIS KILLAM ABELL

A THESIS SUBMITTED IN PARTIAL FULFILLMENT OF THE REQUIREMENTS FOR THE DEGREE OF

MASTER OF SCIENCE

IN

CHILD DEVELOPMENT AND FAMILY RELATIONS 
MASTER OF SCIENCE THESIS

OF

PHYLLIS KILLAM ABELE

APPROVED:

Thesis Committee:

chairman george V-Jitzelle

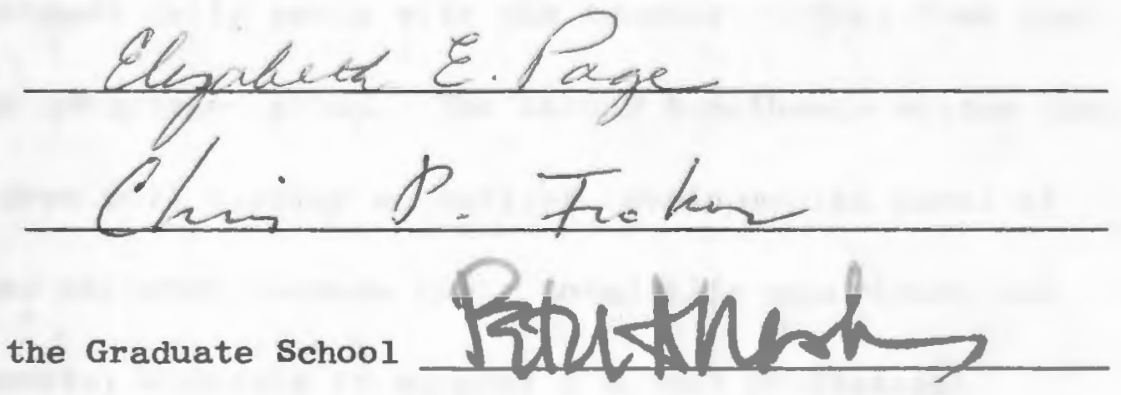

UNIVERSITY OF RHODE ISLAND

1967 


\section{ABSTRACT}

With the increasing awareness in this country of a disadvantaged segment of the population, attention is focused upon determinants of this situation. Congruent with a number of theories in child development, it has been shown that early experiences of the individual have an important influence on the formation of personality. This study is concerned with the observation of some of the effects of early experiences through a comparison of advantaged and disadvantaged pre-school children in a school situation.

It is hypothesized that because of a lesser amount of basic trust on the part of disadvantaged children, the amount and kind of interaction the disadvantaged child seeks with the teacher differs from that of the child in the advantaged group. The second hypothesis states that disadvantaged children will display an earlier developmental level of play than advantaged children because their total life experience has lacked the environmental elements to support a normal progression through the developmental stages.

The methods used in the development of these hypotheses consisted of the observation and tabulation of the frequency of looking, speaking, and touching sought by the child toward the teacher or aides, as well as an evaluation of developmental level of play. This was recorded for a total of eight observations of two-minute intervals each. During the 
first minute the frequency of looking and an evaluation of play level was made. In the second minute the frequency of speaking to the teacher and of touching the teacher was recorded as well as an evaluation of the level of play.

The sample for the study consisted of children, matched for age and sex, and attending nursery schools in which both advantaged and disadvantaged children were present. The criteria for the determination of advantaged or disadvantaged were those used by the Office of Economic Opportunity for admission to Headstart programs.

Following a statistical analysis using the t-test and the Wilcoxon-Mann-Whitney test, the results obtained indicate that there are some differences between advantaged and disadvantaged children. The degree of bias caused by the unequal length of attendance of the two groups at nursery school is difficult to evaluate. However, disadvantaged children sought the teacher or other adults by touching a significantly greater number of times than did advantaged children. Seeking behavior to adults by speaking and looking occurred equally for both groups. It is concluded that this markedly greater seeking behavior by touching may Indicate an affectional deprivation early in the life of disadvantaged children. Basic trust is seen to be present to a lesser degree. The developmental level of play tended to be lower for disadvantaged children than for advantaged children. The results are congruent with the hypothesis, and the interpretation placed upon this relates the results to lack of stimulation by a variety of environmental stimuli in the homes of disadvantaged children, as well as to the influence of lesser amounts of basic trust. 


\section{TABLE OF CONTENTS}

CHAPTER

PAGE

I. THE PROBLEM AND DEFINITIONS OF TERMS $\ldots \ldots \ldots \ldots \ldots \ldots \ldots \ldots \ldots \ldots$

The Problem $\ldots \ldots \ldots \ldots \ldots \ldots \ldots \ldots \ldots \ldots \ldots \ldots \ldots \ldots \ldots \ldots \ldots \ldots \ldots$

Introduction $\ldots \ldots \ldots \ldots \ldots \ldots \ldots \ldots \ldots \ldots \ldots \ldots \ldots \ldots \ldots \ldots$

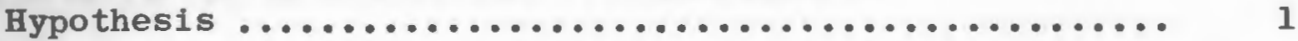

Importance of the study $\ldots \ldots \ldots \ldots \ldots \ldots \ldots \ldots \ldots \ldots \ldots \ldots \ldots$

Definition of Terms $\ldots \ldots \ldots \ldots \ldots \ldots \ldots \ldots \ldots \ldots \ldots \ldots \ldots \ldots \ldots \ldots$

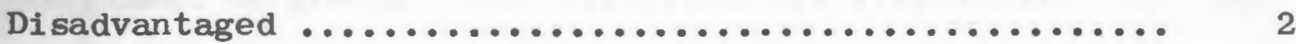

Advantaged $\ldots \ldots \ldots \ldots \ldots \ldots \ldots \ldots \ldots \ldots \ldots \ldots \ldots \ldots \ldots \ldots \ldots \ldots . \ldots \ldots$

Basic trust $\ldots \ldots \ldots \ldots \ldots \ldots \ldots \ldots \ldots \ldots \ldots \ldots \ldots \ldots \ldots \ldots$

Developmental level of play .................... 3

II. THEORETICAL ANTECEDANTS ........................ 4

Affective development ......................... 4

Cognitive development $\ldots \ldots \ldots \ldots \ldots \ldots \ldots \ldots \ldots \ldots \ldots \ldots \ldots \ldots \ldots$

Relationship between Affect and Cognition ............ 7

III. REVIEW OF THE LITERATURE $\ldots \ldots \ldots \ldots \ldots \ldots \ldots \ldots \ldots \ldots \ldots \ldots \ldots \ldots$

Physical environment $\ldots \ldots \ldots \ldots \ldots \ldots \ldots \ldots \ldots \ldots \ldots \ldots \ldots \ldots$

Minimal range of stimuli ..................... 10

Crowding $\ldots \ldots \ldots \ldots \ldots \ldots \ldots \ldots \ldots \ldots \ldots \ldots \ldots \ldots \ldots \ldots \ldots \ldots$

Language $\ldots \ldots \ldots \ldots \ldots \ldots \ldots \ldots \ldots \ldots \ldots \ldots \ldots \ldots \ldots \ldots \ldots \ldots \ldots \ldots \ldots$

Auditory discrimination ...................... 11

Structure $\ldots \ldots \ldots \ldots \ldots \ldots \ldots \ldots \ldots \ldots \ldots \ldots \ldots \ldots \ldots \ldots \ldots \ldots$ 
Maternal Care .............................. 12

Importance of relationship ................... 13

Dependency.$\ldots \ldots \ldots \ldots \ldots \ldots \ldots \ldots \ldots \ldots \ldots \ldots \ldots \ldots \ldots \ldots \ldots \ldots$

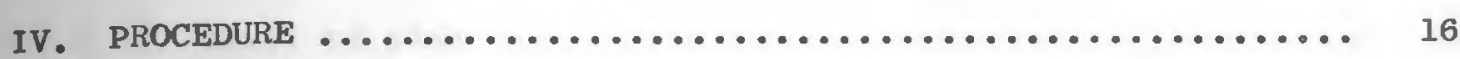

Selection of the Sample $\ldots \ldots \ldots \ldots \ldots \ldots \ldots \ldots \ldots \ldots \ldots \ldots \ldots$

subjects $\ldots \ldots \ldots \ldots \ldots \ldots \ldots \ldots \ldots \ldots \ldots \ldots \ldots \ldots \ldots \ldots \ldots$

Criteria for determination of advantaged or

disadvantaged $\ldots \ldots \ldots \ldots \ldots \ldots \ldots \ldots \ldots \ldots \ldots \ldots \ldots \ldots$

Addition to source of sample .................... 17

Assignment to groups $\ldots \ldots \ldots \ldots \ldots \ldots \ldots \ldots \ldots \ldots \ldots \ldots . \ldots . \ldots 18$

Determination of Units ...................... 19

Definition of teacher interaction categories ......... 19

Description of the level of play ...................... 21

Methods of Obtaining Data ..................... 23

Observation $\ldots \ldots \ldots \ldots \ldots \ldots \ldots \ldots \ldots \ldots \ldots \ldots \ldots \ldots \ldots \ldots$

Records $\ldots \ldots \ldots \ldots \ldots \ldots \ldots \ldots \ldots \ldots \ldots \ldots \ldots \ldots \ldots \ldots \ldots \ldots \ldots . \ldots \ldots$

Order of observation $\ldots \ldots \ldots \ldots \ldots \ldots \ldots \ldots \ldots \ldots \ldots \ldots \ldots$

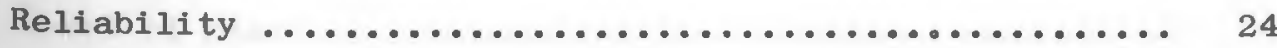

Description of the Schools ...................... 25

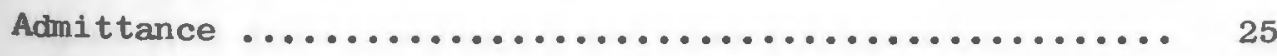

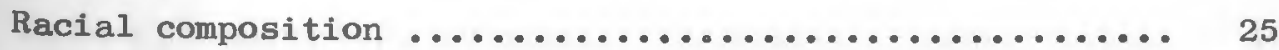

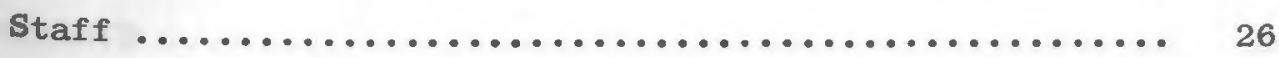

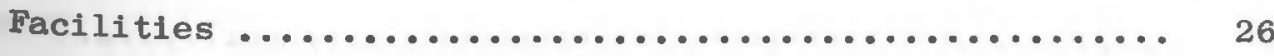


General discussion $\ldots \ldots \ldots \ldots \ldots \ldots \ldots \ldots \ldots \ldots \ldots \ldots \ldots \ldots \ldots \ldots . \ldots 27$

Interaction $\ldots \ldots \ldots \ldots \ldots \ldots \ldots \ldots \ldots \ldots \ldots \ldots \ldots \ldots \ldots \ldots \ldots$

Level of play $\ldots \ldots \ldots \ldots \ldots \ldots \ldots \ldots \ldots \ldots \ldots \ldots \ldots \ldots \ldots \ldots \ldots$

Children and adults in the home ................. 29

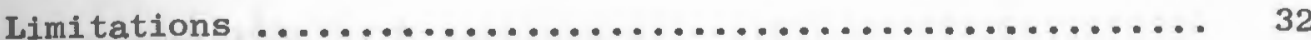

Changing conditions possibly affecting results ....... 32

Randomization $\ldots \ldots \ldots \ldots \ldots \ldots \ldots \ldots \ldots \ldots \ldots \ldots \ldots \ldots$

Comments by the Teachers $\ldots \ldots \ldots \ldots \ldots \ldots \ldots \ldots \ldots \ldots \ldots . \ldots . \ldots 33$

Length of time in nursery school ................. 34

Basis of results and conclusions $\ldots \ldots \ldots \ldots \ldots \ldots \ldots \ldots$

Statistical Analysis ........................ 36

VI. CONCLUSIONS AND RECOMMENDATIONS ................... 40

Conclusions $\ldots \ldots \ldots \ldots \ldots \ldots \ldots \ldots \ldots \ldots \ldots \ldots \ldots \ldots \ldots \ldots \ldots \ldots$

Touching $\ldots \ldots \ldots \ldots \ldots \ldots \ldots \ldots \ldots \ldots \ldots \ldots \ldots \ldots \ldots \ldots \ldots . \ldots \ldots$

Speaking ................................ 41

Looking $\ldots \ldots \ldots \ldots \ldots \ldots \ldots \ldots \ldots \ldots \ldots \ldots \ldots \ldots \ldots \ldots \ldots \ldots \ldots \ldots$

Level of play $\ldots \ldots \ldots \ldots \ldots \ldots \ldots \ldots \ldots \ldots \ldots \ldots \ldots \ldots \ldots \ldots \ldots$

Recommendations ........................... 45

Separation into advantaged and disadvantaged ........ 45

Future research $\ldots \ldots \ldots \ldots \ldots \ldots \ldots \ldots \ldots \ldots \ldots \ldots \ldots$ 


\section{LIST OF TABLES}

TABLE

PAGE

I. Determination of Poverty by the Office of Economic

$$
\text { Opportunity }
$$

II. Distribution of Sample by Age and Sex .............. 20

III. Rank Correlation of Observations ................... 25

IV. Seeking Interaction with the Teacher $\ldots \ldots \ldots \ldots \ldots \ldots \ldots$

v. Per Cent of Total Interaction in Each Category for

Advantaged and Disadvantaged ................... 30

VI. Numbers of Persons in the Home .................... 31

VII. Results of Statistical Analysis ................... 38 


\section{CHAPTER I}

\section{THE PROBLEM AND DEFINITIONS OF TERMS}

\section{THE PROBLEM}

Introduction. With the increasing awareness in this country of a disadvantaged segment of our population, the concomitants of such experience are coming under more careful scrutiny. Congruent with a number of theories in child development, it has been shown that early experiences of the individual have an important influence on the formation of personality. The assumption underlying this study accrues from this very fact: as a result of differing early experiences, there are consequent differences between disadvantaged and advantaged children.

Hypothesis. It is hypothesized: (1) that because of a lesser amount of basic trust on the part of disadvantaged children, the amount and kind of interaction the disadvantaged child seeks with the teacher will differ from that of the child in the advantaged group, and (2) that disadvantaged children will display an earlier developmental level of play than advantaged children because their total 1ife experience has lacked the environmental elements to support a normal progression through the developmental stages.

Importance of the Study. There is a paucity of research on the disadvantaged child. Federal and state programs now in existence are dependent upon relatively little direct research, considering the seriousness and magnitude presently attributed by our society to the problems 
of disadvantaged persons. Research which attempts to provide information concerning the nature of deprivation would seem to contribute to an increased understanding of this phenomena. The intent in this study was to observe an expression of this deprivation, which may indicate some of the special needs that some pre-school children bring to their school experience.

\section{DEFINITIONS OF TERMS USED}

Disadvantaged. This term refers to those children who are members of families with an income equal to or less than that required for admission to Headstart programs. It is the opinion of this author that this economic criterion designates two kinds of deprivation. The obvious one is the economic, which is observed by more persons per room in one living unit, fewer objects for development of concepts, poor langugage use, less parent-child interaction. This leads to the second, an inability of the mother to give sufficient care, both physical and emotional, to the child, even though she is present in the home. A lesser amount of basic trust is expected to be present in this group.

Advantaged. This term here represents those children who are members of families receiving an amount in excess of that required for admission to Headstart programs. Less severe economic deprivation is assumed to be present in the advantaged group. Maternal deprivation is moloubtedly present among some members of the advantaged group, but due to the alleviation of the economic pressures, the maternal care for this group is seen in terms of a greater amount of basic trust. 
Basic trust. This is the term used by Erikson to describe one of two outcomes of the first encounter of the infant with the significant person or persons in his environment. Trust is "an absolute and unquestioning resting on that which is its object."l This concept is extended in this thesis, as has frequently been done in the literature, to include a feeling of security about the internal world as well as the external world.

Bevelopmental level of play. This refers to the degree of interaction in which a child engages with other children and to the form which this Interaction takes. There are six levels of interaction in play which will be described later.

\footnotetext{
${ }^{I_{W e b s t e r}}$ ' Collegiate Dictionary, (Springfield: Merriam, 1947), p. 1074 .
} 


\section{CHAPTER II}

\section{THEORET ICAL ANTECEDANTS}

Differing early experiences of children commence in the prenatal environment and continue after birth through the first encounter with the world. These early encounters can be considered from several different points of view. The particular concern of this study rests with the expression of certain affective and cognitive aspects of behavior at ages three, four and five.

Affective development. Affective development of the individual commences when the infant interacts with significant people in his environment and coordinates these experiences in terms of various erogenous zones of his body. According to Erikson ${ }^{1}$, there is a series of specific stages, which represent decisive encounters of the individual with the person or persons in his environment who are responsible for his care. Brikson states that the first encounter of the newborn is with the mouth and describes it as follows:

His inborn and more or less co-ordinated ability to take in by mouth meets the breast's and the mother's and the society's more or less co-ordinated ability and intention to feed him and to welcome him. At this point he lives through and loves with his mouth. 2

As a result of this first encounter there arises in the infant a basic

${ }_{E}$. H. Frikson, Childhood and Society, (New York: Norton, 1963), pp. 247-274.

${ }^{2}$ Ib1d., p. 72 . 
sense of trust or a basic sense of mistrust, which is the source of feelings the individual has about himself and the world about him throughout his life. The amount of trust which forms in this early experience seems to depend on the quality of the maternal relationship rather than on the perticular quantity of food or specific demonstrations of love. The combination by the mother of that quality of responsiveness to the infant's needs and a sense of personal security within the particular culture creates a sense of trust. For the child this is the basis for the sense of identity which later results in a sense of feeling secure about one's self, of being oneself, and of being someone whom others can trust. 3

Cognitive development. The encounter of the individual or organism with the environment is considered by Piaget4 from the point of view of cognition. Intelligence to him is a particular kind of biological adaptation. He states two relationships which are present between the organism and the environment. According to Flavell's description of Piaget's theory, one essential relationship is adaptation, which "occurs whenever a given arganism-environment interchange has the effect of modifying the organism in such a way that further interchanges, favorable to its preservation are enhanced."5 The other essential relationship Piaget describes is organization, which is the construction of mental structures

3Ibid., p. 249 ${ }^{4} \mathrm{~J}$. Piaget, The Origins of Intelligence in Children, (New York:
Norton, 1963), p. 3. ${ }^{5} \mathrm{~J}$. H. Flavell, The Developmental Psychology of Jean Piaget, (New
York: Van Nostrand, 1963 ), p. 45. 
that are the representation of reality or of the environment. He declares grganization and adaptation to be two complementary processes of a single mechanism, the first which is the external aspect and the second which is the internal aspect of the organism-environment interaction. 6 He says that "It is by adapting to things that thought organizes itself and it is by organizing itself that it structures things."7 Furthermore, he states that intellectual organizations are a totality, in which the interdependence inherent in every organization is expressed. In addition these organizations are thought of in terms of relationships which exist among the elements. 8

In accomplishing adaptation Piaget states that there are two interdependent processes which are active. One, assimilation, Flavell defines as "the process of changing elements in the milieu in such a way that they can become incorporated into the structure of the organism, i.e., the elements are assimilated to the system."9 The second, accommodation, is the process of adjustment of the organism to the specific object it is trying to assimilate. According to Flavell's interpretation of Plaget's theory,

The organism can assimilate only those things which past assimilations have prepared it to assimilate. There must wready be a system of meanings, an existing organization, ufficiently advanced so that it can be modified. ... The subject can incorporate only those components of reality

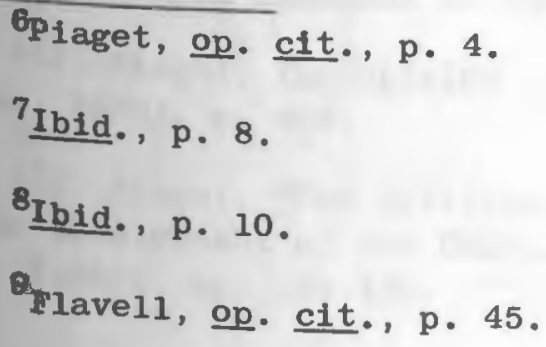


which its ongoing structure can assimilate without drastic change. .... Bxperience is a subtle and complicated affair, the role of which varies with development, and that contact with things always involves the apprehension of a complex of events within a meaning system which organizes them. 10

Piaget describes in various books and publications the development of intelligence in the child, which makes apparent that the perception and interpretation by the child of the world around him changes as he grows from infancy to adulthood. 11 According to Piaget whatever the world presents itself, whatever environmental elements, or "aliments" are present will be used by the child in his interaction with the environment; however few "aliments", or however many there are, will be used. 12

Relationship between affect and cognition. In a brief review of this topic, Piaget ${ }^{13}$ states that affect is a necessary constituent of intelligence. There is no stage of development which is purely cognitive without affect nor purely affective without a cognitive element involved. The presence of affect explains the retardation or acceleration in the formation of structures.

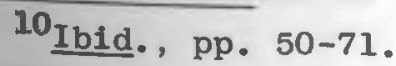

${ }^{11} \mathrm{~J}$. Piaget, The Origins of Intelligence in Children, (New York: Norton, 1963); Play, Dreams, and Imitation in Childhood, (New York: Norton, 1962); The Child's Conception of Number, (New York: Humanities, 1952); The Child's Conception of Physical Causality, (London: Kegan Paul, 1930); The Moral Judgment of the Child, (London; Kegan Paul, 1932). 12J. Plaget, The Origins of Intelligence in Children, (New York:
Norton, 1963), p. 408 .

13J. Piaget, "The Relations Between Intelligence and Affectivity in the Development of the Child," Bulletin of the Menninger clinic, XXVI, (1962), pp. 129-130. 
Plaget expresses his agreement with many theorists that in behavior "the structure is cognitive, and the force or economy, affective."14 He proceeds to point out that these two aspects are complementary, although they are slightly different operationally. The affective, represented by peychoanalytic theory, is characterized by a dominant feature at each stage, however in his theory of cognition, there is a progressive integration between one phase and the next.15 The relevance of these two theories for this study is in their ontogenetic approach to human behavior as well as the emphasis of each theory on one particular aspect of behavior. Although each theory is concerned with only one aspect of development, from an organismic point of view, these different functions are constantly interacting upon each other in the constant lifelong task of assimilating and adapting to the environment.16

With respect to this particular study, disadvantaged children might be expected to experience less basic trust and fewer environmental elements. This would be observed in seeking behavior by the children toward adults, who take the place of parental figures in the school situation. The influence of fewer and less variety of "aliments" upon cognitive development as well as less basic trust would be observed in a lower level of play by the disadvantaged group.

\section{Ibid., p. 131 .}

15 piaget, 10c. cit.

${ }^{16} \mathrm{~J}$. Chambers, "Maternal Deprivation and the Concept of Time," Anerican Journal of Orthopsychiatry, 1961, 31, pp. 406-407. 


\section{CHAPTER III}

\section{REVIEW OF THE LITERATURE}

The comparative literature concerning the early experiences of the advantaged and the disadvantaged is of recent origin. Even the term, cultural deprivation, which is one way to refer to these differences, is a much defined and a much disputed concept. One point of view is that of Riessman, who defines the nature of this deprivation in terms of "those aspects of middle-class culture - such as education, books, formal language - from which these groups have not benefited."I M. Deutsch states that "children from underpriviledged environments tend to come to school with a quantitatively different preparation for the demands of both the learning process and the behavioral requirements of the classroom,"2 and this is a source of difficulty for the child.

Various aspects of poverty and the consequences of these conditions for the child have been described by several authors. There follows a review of recent literature concerned with those aspects of the environment which are considered to have an influence on the physical, cognitive and affective development of the child.

${ }^{1}$ F. Rlessman, The Culturally Deprived Child, (New York: Harper and Row, 1962), p. 3 .

$2_{M}$, Deutsch, "The Disadvantaged Child and the Learning Process," In Depressed Areas, (ed.), A. H. Passow, (New York: Teachers

Columbia University, 1963), p. 163. 


\section{PHYSICAL ENVIRONMENT}

Inimal range of stimuli. There is available in the home of the disadvantaged a minimal range of stimuli. Deutsch ${ }^{3}$ observes that objects of all types are scarce, but especially books, toys, puzzles, pencils, and scribbling paper. These are items which will later be encountered at school, and guidance and explanations previous to the school experience are needed from adults, who in this case do not know or do not have the time to explain. Hunt's interpretation of Piaget states principles, several of which are pertinent here.

...Appropriate stimulation and opportunity to exercise schemata 4 are required for the survival... of the schemata.... The rate of development ..., is a function of environmental circumstances. Change in circumstances is required to force the accommodative modifications of schemata that constitute development. Thus, the greater the variety of situations to which the child must accommodate his behavioral structures, the more differentiated and mobile they become. Thus, the more new things a child has seen and the more he has heard, the more things he is interested in seeing and in hearing. Moreover, the more variation in reality with which he has coped, the greater is his capacity for coping. 5

According to Deutsch 6 the segment of the spectrum of stimulation potential which is available to these children tends to have a less regular ordering of sequences. Dennis's ${ }^{7}$ study of three orphanages in Iran

3M. Deutsch, op. cit., p. 167.

4 Cognitive structures, which have reference to classes of similar action fequences, these sequences of necessity being strong, bounded totalities in which the constituent behavioral elements are tightly interrelated.

$5 \mathrm{~J} . \mathrm{M}$. Hunt, Intelligence and Experience, (New York: Ronald, 1961), pp. 258-259.

$6_{\mathrm{M}}$. Deutsch, op. cit., p. 168.

7. Dennis, "Causes of Retardation Among Institutional Children: Journal of Genetic Psychology, 1960, 96, p. 58. 
gives additional evidence concerning the importance of experience to the development of infant behavior. His opinion was that retardation in two of the institutions was due to the lack of specific kinds of learning apportunities.

Crowding. Hunt $t^{8}$ states that one of the most important characteristics of poverty is crowding, a condition which may have either adverse or positive effects during the first year of life. However during the second year this may have an adverse effect due to the desire of the child for increased locomotion. In the third year imitation of various patterns should be established and should provide a means for learning a language. However the variety of linguistic patterns available is limited and wrong for the standards of later schooling.

\section{LANGUAGE}

Auditory discrimination. The environment is noisy in such crowded conditions. According to C. Deutsch ${ }^{9}$ a child living in such noisy surroundings with little verbal interaction might be lacking in discrimination and recognition of sound. Data gathered early in her study indicated that auditory discrimination was an important factor in verbal Alicrimination. If the child is inattentive to auditory stimuli, then this child will have difficulty with any skill dependent upon this auditory diserimination. There is the implication that "conditions

8J. M. Hunt, "The Psychological Basis for Using Pre-school Enrichment as an Antidote for Cultural Deprivation, "Merrill-Palmer Quarterly, 1964,10, p. 237-238.

${ }^{9} \mathrm{C}$. Deutsch, "Auditory Discrimination and Learning: Social Factors," terrill-Palmer Guarterly, 1964, 10, p. 280. 
under wich children live, particularly early in life, are going to affect auditory skill in a predictable way."10

etructure. Bernstein ${ }^{11}$ analyzes lower class language with regard to structure as containing simple and poorly formed sentences, simple and repetitious use of conjunctions, lack of ability to continue a formal topic through spoken sequences, and a limited and rigid use of adverbs and adjectives. With regard to content he states that the speech form described above discourages the individual from elaborating subjective intent and encourages the expression of descriptive subject matter, rather than orienting the speaker to abstract concepts. M. Deutsch states, similarly, that from his observations the lower class home is not a verbally oriented environment. There is no "practice in auditory discrimination or feedback from adults correcting enunciation, pronunciation and grammar."12 This would seem to encourage inattention and lowers the level of responsiveness.

\section{I. MATERMAL CARE}

The affects of maternal care upon the development of the child are thought by many to have important consequences. These conclusions seem to come from two sources: clinical evidence with concomitant theoretical infrpretations and experimental research. There is much literature

${ }^{10}$ C. Deutsch, op. cit., p. 294.

11B. Bernstein, "Language and Social Class," British Journal of Bociology, 1960, 11, p. 272.

121. Deutsch, op. cit., pp. 170-171. 
from the first source, which will be only briefly referred to here, concerning the early experiences of the child.

Prohoanalytic theoryl3 places an emphasis upon the necessity for an early, satisfying relationship between mother and child. There is much ascription, and these writings include variation in interpretation concerning the consequences of the inadequacy of this early relationship. This arises frimarily from the clinical experience of therapists and is not considered here.

Importance of relationship. Bowlbyl4 emphasizes the importance of the relationship and states:

"for the moment it is sufficient to say that what is believed to be essential for mental health is that the infant and young child should experience a warm, intimate, and continuous relationship with his mother (or permanent mother substitute) in which both find satisfaction and enjoyment."

Stith and Connor state that when this need for satisfaction in contacts with adults has not been met this has been expressed as an extreme dependency on adults. 15

Bopendency. Bxperimental research has served to explore further the nature of this dependency. Gewirtz16 defines the behavior usually associated with emotional dependence as those behaviors used to elicit

13. H. Frikson, Childhood and Society, (New York: Norton, 1963), p. 72; 0. Penichel, The Psychoanalytic Theory of Neurosis, (New York: Norton, 1945), p. 39-41. $14 \mathrm{~J}$. Bowlby, Maternal Care and Mental Health, (Geneva: World
Health Organization, 1952), p. 11.
15M. Stith and R. Connor, "Dependency and Helpfulness in Young 15M. Sitith and R. Connor, "Dependency and
Ghildren", Child Development, $1962,33(1)$, P. 15.

${ }^{16} \mathrm{~J}$. Gevirtz, "Factor Analysis of Some Attention-seeking Behaviors of Young Children", Child Development, 1956, 27(1), p. 17. 
epproval, praise, physical contact, caresses, reassurances, and nearness. Hartup and Keller ${ }^{17}$ characterize dependence as seeking physical contact, being near another person, seeking reassurance, seeking positive attention, seeking help, and seeking negative attention. Stendler 18 lists those aspects of the socializing agent or parent that have reward value as physical contact, mere presence, paying attention, verbal praise or approval, and parental assistance.

The study by Gewirtzl9 is one of the few in this area directly concerned with the effects of socialization. He found that under low availability of the adult the incidence of attention-seeking responses was greater than under high availability of the adult. Hartup and Keller 20 found in a study of nurturance and dependence among pre-school children that there was a positive association between frequency of total nurturance and frequency of seeking help. A negative association was found between total nurturance and being near an adult. Their conclusions were that both seeking help and seeking physical affection, which are in the dependence category, represent direct active attempts

17W. W. Hartup and E. D. Heller, "Nurturance in Pre-School Children and Its Relation to Dependence", Child Development, 1960, 31, p. 684.

${ }^{18} \mathrm{C}$. B. Stendler, "Critical Periods in Socialization and Overdependence", Child Development, 1952, 23, p. 4.

$19 \mathrm{~J}$. Gewirtz, D. Baer, and C. Roth, "A Note on Similar Effects of Low Secial Availability of an Adult and Brief Social Deprivation in Young Children's Behavior", Child Development, 1958, 29, p. 150.

Alartup and Keller, op. cit., p. 687-688. 
ranipulate other people, and that the most passive indirect means that a child can use for securing dependency satisfaction is being near another person. Conclusions drawn by Hattwick 21 seem to agree with this. She says that children are likely to display infantile withdrawing types of reaction in homes which reflect overattentiveness, while there seems to be a positive relationship between aggressive types of behavior and inadequate attention in the home.

Heathers 22 , in a study of independence and dependence of pre-school children, concluded that the process of socialization shows a shift away from a passive infantile dependence on adults to a more active assertive dependence on peers. Ausubel and Ausubel23'state from Sears" "that parental succorance which is abbreviated frustrates the dependency needs of mide-class children and commonly fosters overdependence." They state, however, that there is a difference for these lower class children. "Since it represents the prevailing subcultural norm, and since the opportunity for early anchorage to a free-ranging peer group is available, it tends to encourage the development of a precocious independence."25

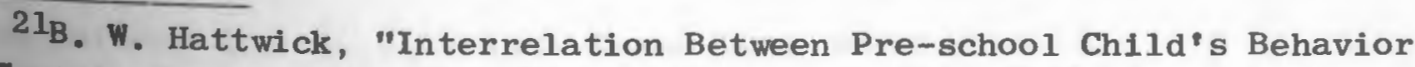
and Certain Factors in the Home", Child Development, 1936, 7, p. 224.

${ }^{22} \mathrm{G}$. Heathers, "Emotional Dependence and Independence in Nursery 8 chool Play", thurnal of Genetic Psychology, 1955, 87, p. 55.

23. Ausubel and P. Ausubel, "Bgo Development Among Segregated Negro Children", "Wtion In Depressed Areas, Passow, ed., (New York: Teachers College, Columbia University, 1963), p. 113.

${ }^{24}$ R. R. Sears, et al., "Some Child-Rearing Antecedents of Aggression and Dependency in Young Children", Genetic Psychology Monographs, 1953, 47, pp. 135-234.

25 Ausubel and Ausubel, 10c. cit. 
CHAPTER IV

\section{PROCEDURE}

\section{SELECTION OF THE SAMPLE}

Subjects. It was decided to use as subjects for this study, children who attended nursery schools in which both advantaged and disadvantaged children were represented. Thus children in both advantaged and Asadvantaged groups within a particular classroom would be responding to the same adults. In order to have an adequate number of subjects, four nursery schools were drawn upon to obtain the sample for this study. The following schools, who in the opinion of the author, the major advisor, and the professional persons at the school had advantaged and disadvantaged children in attendance, were willing to part1cipate in this study: Carter Day Nursery, 249 Public Street, Providence; Nickerson House, 133 Delaine Street, Providence; Salvation Army Day Nursery, 20 Miner Street, Providence; and the Warwick Community Action Nursery School, 2117 West Shore Road, Warwick.

Criteria for determination of advantaged or disadvantaged. The criteria used by the Office of Economic Opportunity in determining the adinitance of children into Headstart programs were used to separate the children into either the advantaged or disadvantaged group. Children who were members of families with an income equal to or less than the levels listed below were considered disadvantaged. Those children who 
were members of families with an income in excess of these criteria were considered advantaged. The criteria used by the Office of Economic Opportunity are listed in Table $I$.

\section{TABLE I}

D TERRINATION OF POVERTY BY THE OFFICE OF ECONOMIC OPPORTUNITY1

Non-farm Households

Persons

1

2

3

4

5

6

7

8

9

10
Family Income

$\$ 1,500$

2,000

2,500

3,000

3,500

4,000

4,500

5,000

5,500

6,000

over 10 , add $\$ 500$ for each additional person.

Medstart Child Development Programs, Community Action Programs Aashington: Office of Economic Opportunity, 1966), p. 13.

Addition to source of sample. Initially the three schools listed first were contacted, and a determination of the composition of the Mildren was made. This revealed that there was a marked preponderance 
of advantaged children with an insufficient number of subjects for the disadvantaged group for this study. It was at this point that the fourth nursery school was introduced. Most of the children attending this school were in the disadvantaged category. In general a majority of the disadvantaged children attended the Warwick Community Action Nursery School, while the majority of the advantaged children attended the Salvation Army Day Nursery.

Assignment to groups. The subjects were divided into advantaged and disadvantaged groups, using the previously mentioned criteria, and using numbers for the subjects instead of names. This latter procedure was used so that the author would not associate any names with either group, and so tend to prejudice the observations. The principal advisor of the author retained the original lists of children sent by each school with the thowing information: name, sex, birth, number of children in the family, number of adults in the family, income and ordinal position in the family. Copies were made for the author omitting the name and substituting an identifying number.

The assignment to age groups ${ }^{2}$ was done using the initial day of beervation, March 13, 1967 for calculation of ages. The following age groups were delineated:

3 years ................. to ... 3 years, 4 months

3 years, 4 months, 1 day ... to ... 3 years, 8 months

3 years, 8 months, 1 day ... to ... 4 years

4 years, 0 months, 1 day ... to ... 4 years, 4 months

${ }^{2}$. Bayley, "Mental and Motor Development from Two to Twelve Years." 

4 years, 4 months, 1 day ... to ... 4 years, 8 months
4 years, 8 months, 1 day $\ldots$ to $\ldots 5$ years
5 years, 0 months, 1 day ... to ... 5 years, 4 months
5 years, 4 months, 1 day ... to ... 5 years, 8 months
5 years, 8 months, 1 day $\ldots$ to ... 6 years

The subjects were then matched within each age group for sex ${ }^{3}$, and all children were used who could be matched. Out of a total of 181 children, 30 matched pairs were selected. After it was decided which children would be used, names from each school were then placed again with the correct numbers, so that the author would know the children in their school situation. When this process was completed it was apparent that it was not possible to have equal numbers of subjects in all age groups. There were few three-year-old children attending these schools, and of these all were female. Approximately half of the matched subjects fell into the four-year-old age groups, and the remainder were five-yearolds. Table II contains the frequency distribution of the sample by age and sex.

\section{DETERMINATION OF UNITS}

Dafinition of teacher interaction categories. In order to evaluate the differing degrees of basic trust which had been experienced by the subjects of the study, attention was focused on that behavioral manifestation which was felt to be most relevant. The amount and kind of interaction sought by the child with the teacher or other adults present in the room was taken as the basis for this measurement. Two-minute intervals for sampling were selected and divided in the following way:

Children A. Hattwick, "Sex Differences in the Behavior of Nursery School Child Development, 1937, 8, pp. 343-355. 
TABLE II

\section{DISTRIBUTION OF SAMPLE BY AGE AND SEX}

\section{Advantaged}

Number Total

in each number in

category

\section{Disadvan taged}

Number Total

in each number in

category each year

3 yrs. -3 yrs. 4 mo.

$\begin{array}{lll}\text { male } & 0 & 0 \\ \text { female } & 0 & 0\end{array}$

3 yrs. 4 mo. 1 day -

3 yrs. 8 mo.

$\begin{array}{lll}\text { male } & 0 & 0 \\ \text { female } & 3 & 3\end{array}$

3 yrs. 8 mo. 1 day -

4 yrs.

\begin{tabular}{|c|c|c|c|c|}
\hline male & 0 & & 0 & \\
\hline female & 2 & 5 & 2 & 5 \\
\hline
\end{tabular}

4 yrs. 1 day -

4 yrs. 4 mo.

$\begin{array}{lll}\text { male } & 1 & 1 \\ \text { female } & 3 & 3\end{array}$

4 yrs. 4 mo. 1 day -

4 yrs. 8 mo.

$\begin{array}{lll}\text { male } & 6 & 6 \\ \text { female } & 3 & 3\end{array}$

4 yrs. 8 mo. 1 day -

5 yrs.

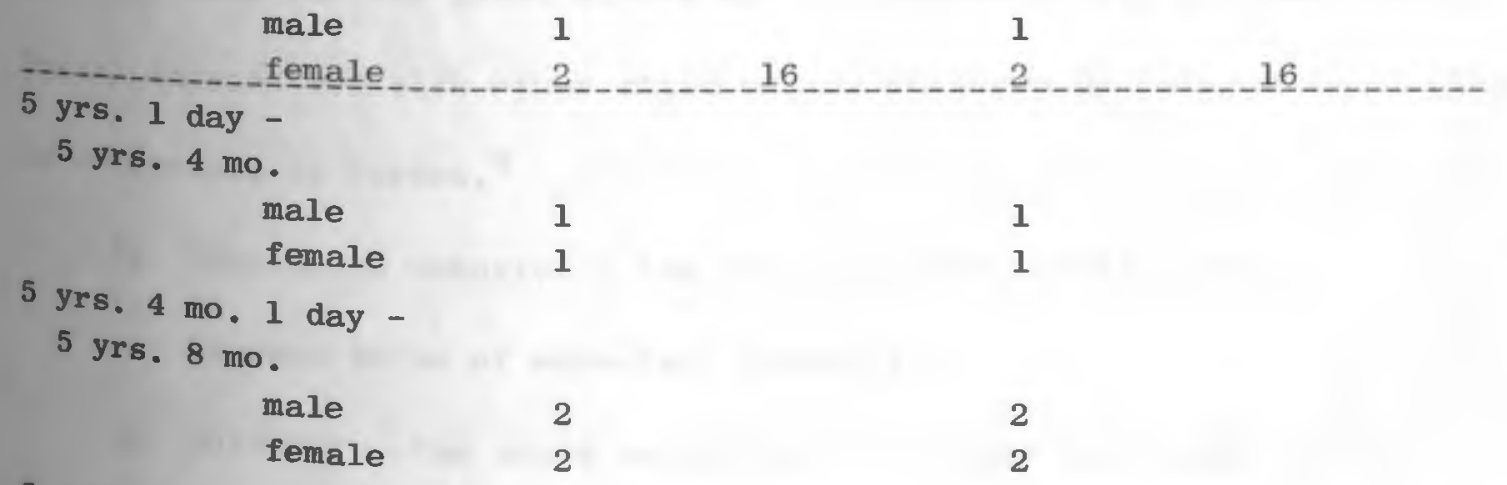

5 yrs. 8 mo. 1 day 6 yrs.

$\begin{array}{llll}\text { male } & 1 & & 1 \\ \text { female } & 2 & 9 & 2\end{array}$


A requency count of the number of times the eyes of the child were drected to the adult was made in one-minute intervals. The count was taken from the beginning of the eyes focusing on the adult until the eyes looked away. The number of seconds was recorded in cases which exceeded fifteen seconds. For each fifteen seconds a frequency unit of one was assigned. The second sequential minute, which was taken following approximately five to fifteen seconds for determination of play category, sampled the frequency of speaking and the frequency of touching the teacher. A frequency unit of one for speaking was assigned to every phrase, sentence or independent utterance, which was separated by a pause. A frequency unit of one for touching was also assigned to the touch category for any duration of touch less than ten seconds. Every ten seconds thereafter was assigned a frequency unit of one. Eight such two-minute samples were taken for each child over a period of approximately three weeks.

\section{Pascription of the level of play. A determination of the level of} play was made for the first minute and the second minute of observation. Bocial interaction with other children was measured by categories of play as dotermined by Parten. 4

1. Wnoccupied behavior - the child watches anything that happens to be of momentary interest.

2. Onlooker - the child definitely observing particular groups of children and may talk with them.

\footnotetext{
4M. B. Parten, "Social Participation Among Pre-school Children," Journal of Abnormal and Social Psychology, 1932, 27, p. 249-251.
} 
3. Solitary - the child plays alone with toys different from those close by, making no effort to get close to or speak to others.

4. Parallel - the child plays independently with toys that are like those around him, and does not try to modify or influence the activity of the children near him.

5. Associative - group play in which there is overt recognition by the group members of their common activity, interests, and personal associations, but each child acts as he wishes.

6. Cooperative - the child plays in a group that is organlzed for the purpose of making some material product, or of striving to attain some competitive goal, or of dramatizing situations of adult and group life, or of playing formal games. There is a marked sense of belonging or not belonging to the group. Control of the group situation is in the hands of one or two members who direct the activity.

\section{METHOD OF OBTAINING THE DATA}

Dervation. Data for this study were obtained by observing the subjects in their school situation. All observations were recorded while the children were engaged in free play, that is, the subject was free to choose where he or she would play, what play materials would 
be used, and with whom he would play. All of the schools participating in this study had at least one period daily for this kind of activity. Records. The frequency of the child's seeking interaction with the teacher in the previously described categories was recorded instanteneously on $4 \times 6$ cards especially prepared for this purpose. A replica is shown below.

LOOK SPEAK TOUCH

MORDS SPOKEN

NO.

All Information taken in the two-minute interval was recorded on this form. Mriginally, it was planned to place the play evaluation on the back of this card, but in actual use the play evaluation was recorded at the base of the appropriate columns. An attempt was made to record the speech of the child, but it was not always possible to understand every word the child said under the conditions of these observations. 
Order of Observation. Order of observation was determined by molonizing. Prior to observing children in a particular classroom, a card upon which the name and identification number appeared was placed with the other such cards for that room. These cards were shuffled three times with an equal number of blank cards. The order for observation was thus established for each group of children each time they were observed. A record of this protocol was kept. The occurrence number, the order number, and the identification number along with the name of the child were then transferred to the observation record card.

Reliability. Simultaneous observations by the author and principal advisor of individual children were made for two one-minute intervals in the peviously described categories. This procedure was carried out at the University of Rhode Island Child Development Center. A total of 109 observations were made, which included training sessions, concurrent ovaluation of observations and gradual reduction of errors and difficulties encountered. After the initial observations a trend toward Increased accuracy was noted. Reliability of the last 20 observations, Ptermined through rank order correlation of the simultaneous observation of each judge, is given below in Table III. 
TABLE II I

\section{RANK CORRELATION OF OBSERVATIONS}

\begin{tabular}{lc} 
Category & $\tau$ \\
\hline look & .965 \\
speak & .992 \\
touch & .983 \\
level of play & .996 \\
\hline
\end{tabular}

\section{Description of the Schools}

domittance. The three privately operated nursery schools (Carter Day Nursery, Nickerson House, Salvation Army Day Nursery) required evidence of need on the part of the family for the child to attend, and payment for this service according to the family's ability to pay. The Marwick Community Action Nursery School required that the income of the family meet the Office of Economic Opportunity criteria, and the children attended free of charge.

\section{Bacial Somposition. The children attending the private nursery} gchools were a racially mixed group, while the children attending the Iourth were white. No attempt was made to record race since it was not midered by this author to be a significant variable for this research. Casual observation of the children in their school situation seemed to be in accord with this. 
Staff. In each school there was at least one professional person with each group of about 15 children. In addition, there were from one to three aides, who were either paid professional assistants or Job Corps persons. In the case of the Warwick school, a combination of Job Corps young persons and women, who were regular volunteers, assisted. At Carter Day Nursery there were nuns as assistants rather than young girls from the Job Corps. The variation in the number of aides is partially a result of the difference in the number of children in one class as compared to another class, as well as the different physical situation of each school, and the philosophy of the particular school concerning the desirability and function of aides.

Tecilities. The physical situation was different in all cases. At Carter Day Nursery, the school rooms were large, and well-lighted with a variety of play materials. There were separate facilities for both indoor and outdoor active play. At Nickerson House the area for each age group must be close to minimal. Facilities and the play materials were very good; there was an outdoor play area here. The Salvation Army Day Jursery had large, well-lighted rooms with not as many play materials in evidence, but the necessary items were there. An outdoor play area was present here also. The Warwick Community Action Nursery School had one very large room for about 50 children. This had been subdivided with Mokcases and movable partitions into various sections. However, the sound carried quite easily in this large area, so that the noise level seemed to be higher than at the other schools. An outdoor play area was available here also. 
CHAPTER V

\section{RESULTS}

\section{GENERAL DISCUSSION}

In this comparative study of advantaged and disadvantaged children's seeking behavior toward adults, some differences were apparent. The statistical analysis appears in the last section of this chapter and a general (1) scussion of the results, in addition to a more specific delineation of seeking behavior and developmental level of play in terms of frequencies, follows. Disadvantaged children initiated seeking behavior with greater frequency than advantaged children. The level of play of the disadvantaged group was lower than that of the advantaged group. Differences appeared between advantaged and disadvantaged children in the amount and kind of interaction.

toraction. In seeking interaction with the teacher, disadvantaged children did slightly more looking than advantaged children. Disadvantaged children also spoke to the teacher more often. Seeking behavior toward the teacher by means of touching occurred with much greater frequency for disadvantaged children than for advantaged children. Table IV shows the frqquencies of these behaviors. With regard to seeking behavior and role bhavior of children toward nuns as teachers, from casual observation, it appeared to the author that children at this school perceived the nuns as teachers in the same way that children in the other schools regarded their teachers.

With geference to the proportion of these three behaviors within each of the groups, the greatest per cent of seeking behavior for both advantaged and disadvantaged children was in looking. For disadvantaged 
wildren proximately 78 per cent of this seeking was in looking, while for disadvantaged children approximately 67 per cent of their interaction was in looking. With reference to speaking there was approximately an equal per cent for both groups. For advantaged children roughly 15 per cent of their seeking an adult was expressed verbally, while the orresponding percentage was 16 for disadvantaged children. However, distinctive differences were present in the third category. Touching behavior occurred in approximately 16 per cent of the disadvantaged group's total responses, while for advantaged children, only seven per cent of their entire seeking behavior took place by touching.

TABLE IV

SEEKING INTERACTION WITH THE TEACHER

Look Speak Touch Total

Total frequency for 2 observations

advantaged

$\mathrm{n}=30$

disadvantaged

$\mathrm{n}=\mathbf{3 0}$

Total

advantaged

$\mathrm{n}=20$

423

96

46

565

Hadvan taged

$\mathbf{n}=20$

467

113

96

676

Total

Total frequency for 8 observations
890 
A contrast in the kind of interaction expressed by the advantaged and the disadvantaged group is summarized in Table $V$. There seemed to be a pogressively greater discrepancy between the two groups in exressing seeking behaviors, which occurred sequentially from looking, to egeaking, to touching. More specifically, there was an approximately equal per cent of looking in advantaged responses and in the disadvantaged responses, while speaking behavior tended to be sought to a greater extent by disadvantaged children than by advantaged children. However, touching interaction is sought by the disadvantaged group in a much greater portion of their total seeking interaction with the teacher than it was sought by advantaged children.

Ievel of Play. Some difference in the level of play of the disadvantaged as compared to the advantaged group was present. The level of play characteristic of the advantaged children was at the low parallel level, while disadvantaged children tended to play at a high solitary level.

Children and adults in the home. Differences were apparent in the number of children present in the families of the two groups used for this study. The mean number of children was 4.00 in the disadvantaged sub-group of 20. In the corresponding sub-group of advantaged children, the mean number was 2.78 .

With regard to the number of adults present in the home marked dissimilarity appeared. In 75 per cent of the advantaged homes there were two adults, however, in only 40 per cent of the disadvantaged homes 
TABLE V

PER CENT OF TOTAL INTERACTION IN EACH CATEGORY FOR ADVANTAGED AND DISADVANTAGED

2 observations

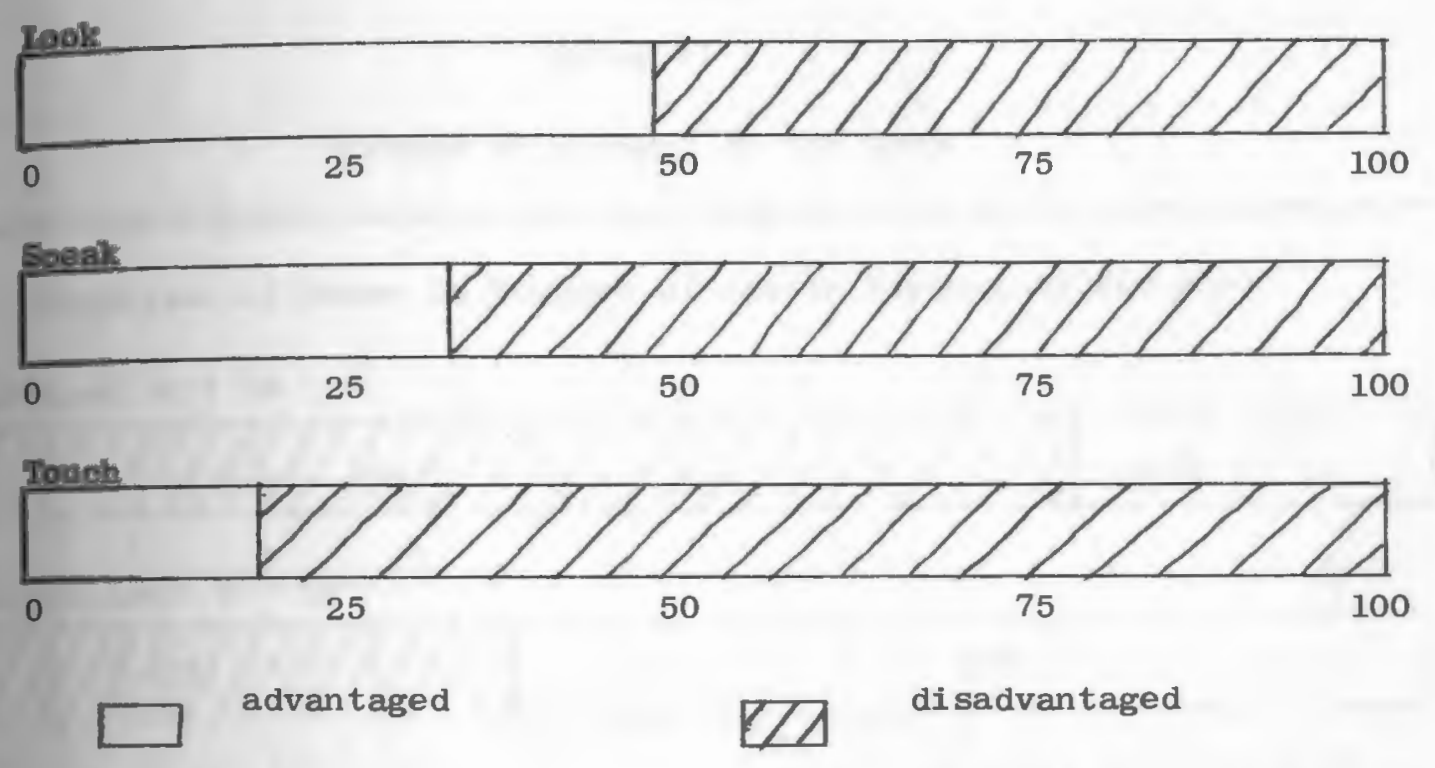

8 observations
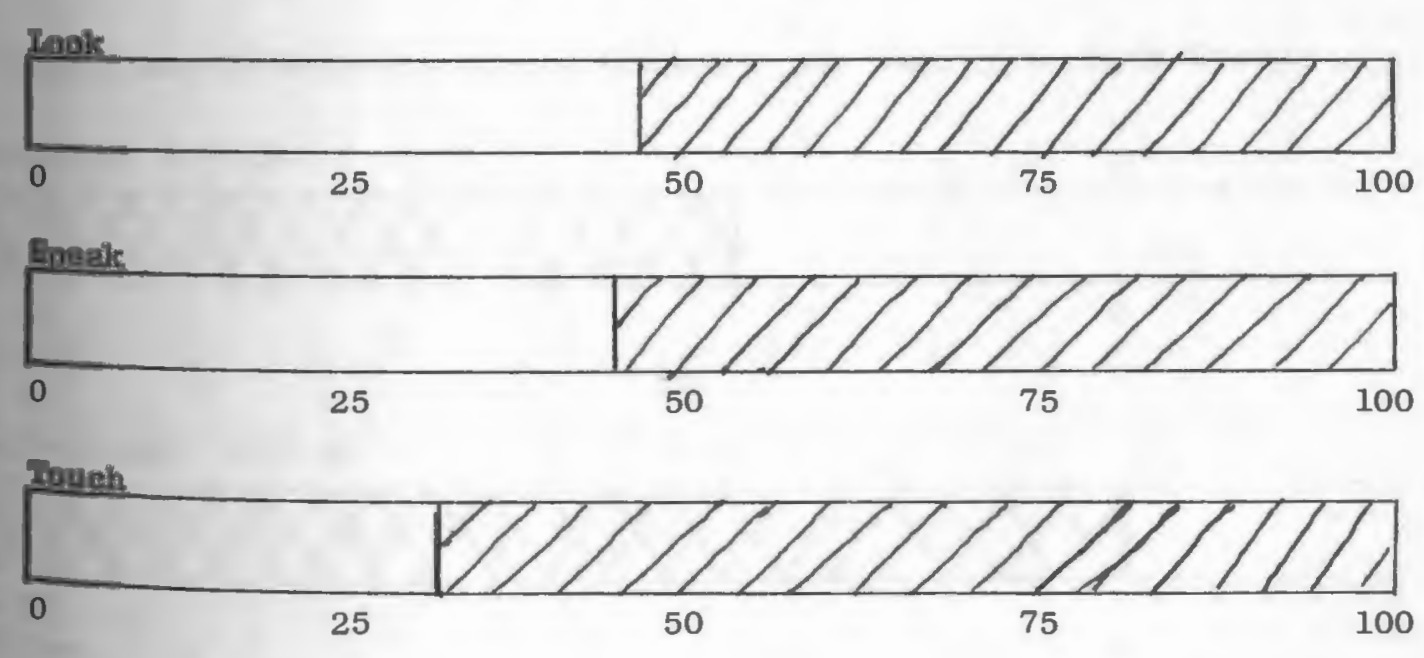

$\square$ advantaged

D disadvantaged 
there vere two adults present. This means that 60 per cent of the homes wich were classified as disadvantaged in this study have only one adult present. Table VI presents the information in this section graphically.

\section{TABLE VI}

NUMBERS OF PERSONS IN THE HOME

Comparison of Homes in Numbers of Adults Present by Per cent

Advantaged $\mathrm{n}=20$

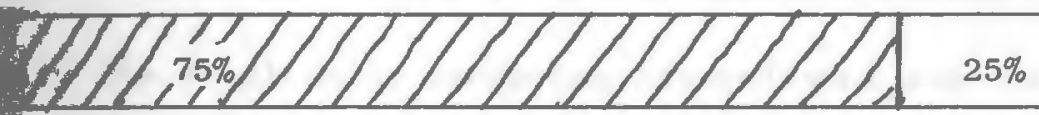

Disadvantaged $\mathrm{n}=20$

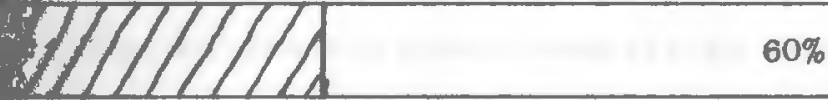

UD] 2 adults present

1 adult present in home

Comparison of Mean Numbers of Children per Family in Both Groups

Advantaged $\mathrm{n}=20$

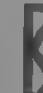

No. of

Children

2 .

3

4

Dsadvantaged $n=20$

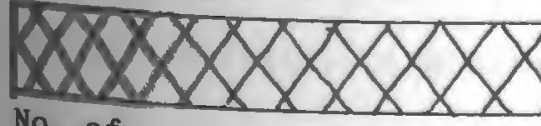

No. of

औildren

1

2

3

4

5 


\section{LIMITATIONS}

Changing conditions possibly affecting results. The one major change, which may have materially affected the results of this study, was the change in the composition of the groups observed. At the commencement of observation the attendance at all of the nursery schools was the usual approximate of 90 per cent. Several weeks after this there was a local outbreak of mumps in two nursery schools, and chicken pox in another; however the attendance in one school remained relatively stable with only the usual colds producing intermittant absences. Three of the schools were so affected that during the last 10 days of observation only 50 per cent of the children normally in class were in attendance. At two of the schools this was the period that a large portion of the disadvantaged children were observed.

This situation substantially altered the ratio between the subjects and the adults present in the room, as well as reducing the number of whildren, which could then influence their relationship with each other. Desearch by Gewirtzl indicates that children sought adults with greater frequency when they were less available than when the adults were more easily available. A similar influence may have been exerted on the present group.

The initial procedure had been to make a total of 10 observations for each child. However due to the magnitude of the illnesses among the children, in addition to the expectation on the part of the teachers

\footnotetext{
laewirtz, op. cit., p. 150
} 
that nother decrease in school attendance might ensue because of a public school vacation, it was decided to conclude this study with eight olbervations.

indomization. In the school rooms that the author was observing as many as 15 to 20 children, the changing character of the attendance Alluenced the random order for that particular day. For those children present on a particular day, the scheduled random order was followed. On the vucceding day, a check was immediately made to ascertain if those absent previously were in attendance, and if so these observations were made first, keeping to the schedule that had been arranged.

Comments by the teachers. Several observations by teachers of some of the children included in this study are pertinent. One teacher stated that even though a number of the children in her classroom were by my criteria classified as advantaged, she considered them disadvantaged. When asked what she meant by disadvantaged, she said that they lacked many cultural opportunities at home such as books. The parents were tostly factory workers and not professional persons.

Whother teacher, in whose classes the majority of the disadvantaged children in this study were present, said that their behavior in many respects was different now than when they first came to school. Initially these mildren did not know how to use the blocks, nor the housekeeping corner. Dramatic play did not seem to be a means of expression for them. Bhe stated that it was necessary for the teachers to devise many ways to show the children how these materials could be used. At first the children ate as if there was "no tomorrow", but this gradually changed, 
and they now have a sense of security at school; the children trust the teachers.

This same teacher also had a number of comments about the families of these children. She said that the families didn't seem to eat together much, which seemed to be generally charactertistic of a lack of organization in their lives. A sense of time seemed also to be lacking. She felt that they were good parents and sincerely loved their children, but they had so many problems. These comments, taken together, suggest the fresence of deprivation among both the advantaged and disadvantaged groups. Discrete groups might have provided a better test for the llypotheses.

Length of time in nursery schoo1. The duration of attendance might well be a consideration for variability of seeking behavior toward adults in a nursery school situation, in addition to the variation with regard to age and sex. Attendance records were obtained and a WilcoxonMann-Whitney test, using a level of significance of .05, was calculated for differences between advantaged and disadvantaged children with regard to length of stay. ${ }^{2}$ These results indicate that the advantaged children have been attending nursery school a significantly longer time than disadvantaged children. Some of this difference may be due to the sampling Hocedure, which included a recently established nursery school enrolling large numbers of disadvantaged children. The Headstart school, from

$$
{ }^{2} \text { For } H_{0}: F\left(X_{A}\right) \equiv G\left(X_{D}\right) \text { vs. } H_{a}: F\left(X_{A}\right)>G\left(X_{D}\right) \text {, at } \alpha=.05 \text {, the }
$$
is 2.89 . 
wich pproximately half of the disadvantaged children in this study were drawn, has been in existence only since 1966, while the other chools have been in operation for a number of years.

Although Increasing length of time in nursery school might be expected to reduce seeking behavior, the degree of influence cannot be precisely estimated. However, one factor which may have served to limit the bias of the results was the allowance in the study for initial gijustment of both groups of children to nursery school. Only two children in the disadvantaged group and one child in the advantaged group spent less than two months in school prior to the study. The disw advantaged group had attended school for a mean number of 6.4 months, wille the advantaged children had been in school for a mean of 13.8 months. Teachers of disadvantaged children noticed considerable changes in seeking behavior during the first several months. Initially, according to several teachers, disadvantaged children sought much more interaction with adults in the classroom than advantaged children, but after several months, this seeking behavior decreased and remained fairly stable thereafter.

Basis of results and conclusions. The data were then analyzed on the basis of two observations, which was the most number of observations available for the entire original sample size of 60 subjects, as well as the observations being taken prior to the time of numerous absences. The data were also analyzed on the basis of eight observations with the abbreviated sample of 40 subjects. Conclusions were then made on the basis of both of the conditions and sample sizes. Tables are shown in 
gome cases with data from two observations as well as for the eight observations.

\section{STATISTICAL ANALYSIS}

Both the t-test and the Wilcoxon-Mann-Whitney test were utilized to Trestigate if there was any significant difference between the two groups in each category at a level of significance of .05. A two-sided t-test ${ }^{3}$ was used for the categories under interaction. A one-sided Wilcoxon-Mann-Whitney test ${ }^{4}$ was used for the level of play and for the tegories of interaction.

The decision to use both parametric and non-parametric methods of analysis lay in the character of the frequency distribution. The distribution for the look category and for the total interaction appeared normal; however, the distributions for the speak and touch categories appeared to be skewed. The variances of all categories were found to be equal. Thus the assumptions of normality and equality of variance for the t-test were met for only two of the four categories. A matched pairs analysis was not utifized because the actual composition of the groups by sex and age made this a less desirable method. An analysis of differences between the advantaged and disadvantaged groups could be whieved with greater relevance for this cross sectional study by using individual frequencies within each group.

Due to the previously described changing conditions hypothesis 1 and

${ }^{3}$ Chris P. Tsokos, Statistics 111, (course given at the University of Rhode Island, Kingston, Rhode Island, Fall 1966). ${ }^{4} \mathrm{H}$. C. Fryer, Concepts and Methods of Experimental statistics, Allyn and Bacon, 1966), pp. 190-192. 
hypothesis 2 were tested using the t-test for two sets of data: data from the sample size of 60 with two observations, and data from the gample size of 40 with eight observations. Since the larger number of of Mrvations would be a better population estimate, the Wilcoxon-MannWhitney test was used only for the sample size of 40 . The results of the thtistical analysis are found in Table VII.

The results of this analysis using both tests are as follows: at the five per cent level of significance there were no significant differences in looking or speaking behavior or for total interaction sought. However, the two groups were significantly different in touching behavior. Using the Wilcoxon-Mann-Whitney test to evaluate differences in developmental level of play, there was no significant difference in the level of play at the specified level of significance; however, at a level of Eignificance of .10 the level of play of the disadvantaged group is lower than that of the advantaged children. 
RESULTS OF STATISTICAL ANALYSIS

t-test, $\quad t=\bar{x}_{A}-\bar{x}_{D}, \quad s^{\# 2}=\left(n_{A}-1\right) s_{A}^{2}+\left(n_{D}-1\right) s_{D}^{2}$

$$
\mathrm{s}^{\#} \sqrt{\frac{1}{\mathrm{n}_{\mathrm{A}}+\frac{1}{\mathrm{n}_{D}}}}
$$$$
\mathrm{n}_{\mathrm{A}}+\mathrm{n}_{\mathrm{D}}-2
$$

$\mathrm{H}_{\mathrm{O}}: \mu_{\mathrm{A}}=\mu_{\mathrm{D}}$ vs. $\mathrm{H}_{\mathrm{a}}: \mu_{\mathrm{A}} \neq \mu_{\mathrm{D}}, \alpha=.05$

t-values calculated from data, $n=30$ values from $t$ distribution for $D F$, $\alpha=.05$

$\begin{array}{lr}\text { look } & .33 \\ \text { speak } & 1.30 \\ \text { touch } & 2.47 \\ \text { total interaction } & 1.69\end{array}$

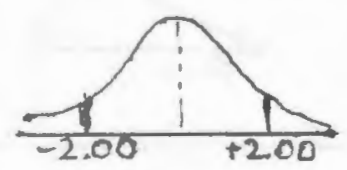

$$
t_{58, .975}=2.00
$$

$t$-values calculated from data, $n=20$ values from $t$ distribution for $D F$, $\alpha=.05$

$\begin{array}{lr}\text { look } & .73 \\ \text { speak } & .53 \\ \text { touch } & 2.02\end{array}$

total interaction 1.32

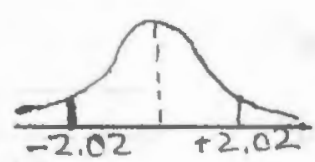

$$
t_{38, .975}=2.02
$$

Means for $\mathrm{n}=30,2$ observations

advantaged disadvantaged

$\begin{array}{lrr}\text { look } & 5.40 & 5.76 \\ \text { speak } & .83 & 1.56 \\ \text { touch } & .40 & 1.96 \\ \text { total interaction } & 6.63 & 9.30\end{array}$

Heans for $\mathrm{n}=20,8$ observations

$\begin{array}{lcccc}\text { look } & \text { advantaged } & \text { disadvantaged } & \text { advantaged } & \text { disadvant } \\ \text { speak } & 21.15 & 23.35 & 10.23 & 8.10 \\ \text { touch } & 4.80 & 5.65 & 4.21 & 5.43 \\ \text { total inter- } & 2.30 & 4.80 & 3.14 & 3.39 \\ \text { action } & 28.25 & 33.80 & 12.37 & 13.36\end{array}$

standard deviation, $\mathrm{n}=20$ advantaged disadvantaged advantaged disadvantaged 
test for equality of variance, $F$ test, $F=\frac{s_{A}^{2}}{s_{D}^{2}}$

$\mathrm{H}_{0}: \sigma_{\mathrm{A}}^{2}=\sigma_{\mathrm{D}}^{2}$ vs. $\mathrm{H}_{\mathrm{a}}: \sigma_{\mathrm{A}}^{2} \neq \sigma_{\mathrm{D}}^{2}$

$F$ values calculated from data, $\mathrm{n}=20$ value from $\mathrm{F}$ distribution for $\mathrm{DF}$,

$\begin{array}{lll} & & \text { of }=.05 \\ \text { look } & 1.59 & \\ \text { speak } & 1.66 & \\ \text { touch } & 1.85 \\ \text { total interaction } & 1.17 \\ \text { level of play } & 1.25 & \text { F.16 }\end{array}$

Vilcoxon-Mann-Whitney test, $U=\mathrm{n}_{A^{n}} \mathrm{n}_{\mathrm{D}}+\mathrm{n}_{\mathrm{A}}\left(\mathrm{n}_{\mathrm{A}}+1\right)-\mathrm{T}$

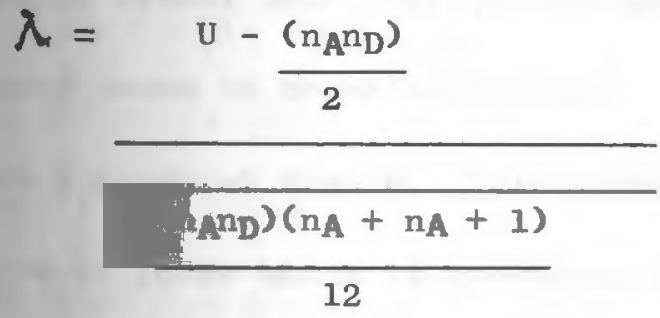

$$
\begin{aligned}
& 2 \\
& \mathbf{n}_{\mathbf{A}}= \text { number in advantaged group } \\
& \mathbf{n}_{\mathbf{D}}= \text { number in disadvantaged group } \\
& \mathbf{T}=\text { sum of ranks of the } \mathbf{x}_{\mathbf{A}} \text { in } \\
& \text { combined array }
\end{aligned}
$$

\section{$\mathrm{H}_{0}: \quad F\left(\mathrm{X}_{\mathrm{A}}\right) \equiv \mathrm{G}\left(\mathrm{X}_{\mathrm{D}}\right)$ vs. $\mathrm{H}_{\mathrm{a}}: \mathrm{F}\left(\mathrm{X}_{\mathrm{A}}\right)>\mathrm{G}\left(\mathrm{X}_{\mathrm{D}}\right)$}

values calculated from data, $n=20$, value from $\lambda$ distribution

$\begin{array}{lr}\text { look } & .91 \\ \text { speak } & .20 \\ \text { touch } & 1.70 \\ \text { total interaction } & 1.34\end{array}$

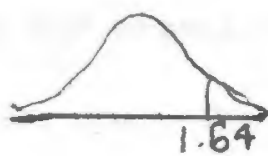

$$
\begin{aligned}
\lambda & =1.64 \\
(\lambda & =1.28, \\
\alpha & =.10)
\end{aligned}
$$

$\mathrm{H}_{\mathrm{O}}: \mathrm{F}\left(\mathrm{X}_{\mathrm{D}}\right) \equiv \mathrm{G}\left(\mathrm{X}_{\mathrm{A}}\right)$ vs. $\mathrm{H}_{\mathrm{a}}: \mathrm{F}\left(\mathrm{X}_{\mathrm{D}}\right)>\mathrm{G}\left(\mathrm{X}_{\mathrm{A}}\right)$

level of play $\quad 1.45$

$$
\begin{gathered}
T=\text { sum of ranks of the } x_{D} \\
\text { combined array }
\end{gathered}
$$




\section{CHAPTER VI}

\section{CONCLUSIONS}

Touching. The conclusions of this study further document the mountIng evidence concerning differences between advantaged and disadvantaged children in this country. A qualitative comparison of the kind of interaction sought by disadvantaged and advantaged children yields significant Afferences. Disadvantaged children seek interaction by touch to a greater extent than their advantaged counterparts. This greater frequency seems to be an expression of greater desire for physical contact with a parental figure. This greater frequency also implies that the drive or force which is expressed in this behavior of disadvantaged Mhildren exceeds that of advantaged children.

Brikson' $\mathrm{s}^{1}$ culturelly oriented view of drive gives added dimension to this. He states that the various drives of the child are merely fragments to be given meaning and organized during a long childhood in the context of a particular culture. The emphasis which Erikson places upon mperience is supported in this study. In the particular cultural Wh-culture of the disadvantaged, one of the differential meanings and organization of their experiences is expressed by this stronger drive as a part of adaptation to a particular life experience. A deprivation of an affectional kind seems to be present in which a resultant lesser

\footnotetext{
IErikson, ㅇp. it., p. 95.
} 
amount of basic trust is experienced. Information concerning the number of chlldren and the number of adults in the home of the children used in this tudy lend support to this conclusion. The presence of only one adult in the majority of the disadvantaged homes in addition to the presence of a greater number of children may indicate some of the reasons for this.

Bpeaking. The fact that disadvantaged children seek interaction by peaking in the nursery school situation to an equal degree as advantaged children is significant when the information available concerning the structure and content of verbal interaction is taken into masideration. However, from research cited previously, the structure and content is apparently different for the advantaged group. It would seem from the description of syntax and content and the statement that the didvantaged home is a non-verbal one, that the seeking behavior expressed by disadvantaged children would be less than that expressed by advantaged children. The results of this study are contradictory to this expectation. Quantitatively, disadvantaged nursery school children do actively desire as much verbal interaction as advantaged children. This Implies that social interaction by means of verbal communication is a real mode of expression for these children, even though the form and content may be at variance with the children who have experienced more advantaged environments.

The difference in expectation on the part of the author on the pasis of the literature and in the outcome of this study may indicate that the results could also be interpreted as the expression of the 
fience of a lesser amount of basic trust. A third explanation is ancerned with the effect upon these children of nursery school attendance of a minimum of four to nine months to a maximum in some cases of over a year, in which verbal communication is encouraged.

Looking. Both advantaged and disadvantaged groups expressed seeking hteraction with adults by similar amounts of looking. Looking is a less direct, more passive means of communication than either speaking or touching. It does, however, comprise the greater portion of seeking behavior for both groups, which can be interpreted to mean that the need of both groups of these children to perceive visually the adults in their school is of equal strength. Spatial orientation of the child with respect to the adult may be expressed by this behavior, as well as curiosity relevant to the ongoing physical, affective and cognitive behavior of the teacher. The possibility that deprivation exists in both groups might explain the fact that both groups use this rather passive approach to social interaction to a great extent.

Level of play. The results of this study show a definite tendency for the level of play of disadvantaged children to be at an earlier level than that of advantaged children. This would indicate further that there are ditferences in the early experiences of disadvantaged children, which are proressed by this earlier level of play.

It has been previously reported that the homes, which disadvantaged children come from, are lacking in the variety of toys and objects. The children also experience lack of familiarity with materials that are incountered in school. Less opportunity is therefore present for these 
children to accommodate to and assimilate environmental elements, which acording to Plaget, is the basis for the continual process of adaptation and organization. Assimilation takes place with reference to objects only when past assimilations have prepared the child to adapt to that iticular object. This presupposes that there exists a system of meanings to apprehend the contact with elements. There seems to be less variety and fewer objects for these children to come in contact with, and therefore there is less stimulation from the environment of the disadvantaged.

From an organismic point of view, it is relevant to include the Influence of basic trust upon the interaction of children with each other as well as upon cognitive development. It therefore seems plausible here to conclude that a lesser amount of basic trust may be a factor in the Afferential level of play of the two groups as well as the more obvious lack of environmental stimuli.

The school situation has increased the stimulation by offering a rich variety of color, shapes, textures, and other play materials for cognitive development. Since the children who are subjects for this study have been attending nursery schools continuously for a number of months, there has been some opportunity for cognitive development to proceed more rapidly.

In Chapter IV, limitations were noted concerning the duration of attendance at nursery school and the changing composition of the classes. The effect of these limitations upon the conclusions of this study is difficult to evaluate. Seeking behavior on the part of all children 
might tend to decrease as a result of the change in the teacher-pupil ratio, while the effect of differential length of time in school cannot be precisely estimated.

Within the limitations noted previously, the interaction sought by disadvantaged children differed from advantaged children in touching Mehavior. The level of play of disadvantaged children tended to be less than advantaged children. 


\section{RECOMMENDATIONS}

Separation into advantaged and disadvantaged. The criteria used by the Office of Economic Opportunity for admission to Headstart programs has been an effective one for the separation of the children in this study into two disparate groups. The marked contrast in the number of adults present in the home and the number of children in each family is evidence of the relative difference. However, in terms of this study the naration seems to the author to be, in a number of cases, a separation between less severe poverty and more severe poverty, rather than a epparation between poverty and the economic sufficiency of the middle class. It seems to the author and principal advisor that this study was a very severe test of the hypothesis. The original intent of this project had been to contrast more nearly middle class children with those whose family income would gain admittance to Headstart programs.

Two recommendations are made by this author for additional criteria in order to provide a more adequate division into advantaged and disadvantaged groups. One suggestion is concerned with a change in the criteria for the determination of the advantaged group by increasing the lower limit of the per capita income set by the Office of Economic Opportunity. For example, $\$ 1500$ would be added for each member of the family, rather than the $\$ 500$ limit set for admission to Headstart programs. This would possibly eliminate marginal or less severe poverty and provide for two groups that are in greater contrast. 
Another suggestion, which has been useful in other studies and would seem to achieve the same result, is use of information concerning the occupation of the father or mother. Although this adds a non-economic criterion, it might well be useful in terms of the selection of an advantaged group for a similar comparative study. Riessman has noted that deprivation results from lack of many factors, which might be expected to be represented differentially in a continuum of varying professional status.

Future Research. The problems encountered in this study make apparent the difficulties facing anyone who attempts to do research in the complex area of human behavior. A consideration of the relevant variables is uppermost for meaningful research in child development. The problem of differentiating between behavioral differences as a result of a certain length of time of nursery school attendance and those differences resulting from maturational inequalities relating to age and sex is a dificult one indeed. This could be an area for future study.

In order to ascertain differences in seeking behavior of advantaged and disadvantaged children, a sample of four year-old nursery school children should be used, in which 20 boys and 20 girls comprised each group. Ideally, both advantaged and disadvantaged children, matched for age, sex and length of time in nursery school, and attending the same school with the same teacher and assistants, would be part of the design of the experiment. A more practical procedure, however, would be the use of eight to ten nursery schools, so that the personality of the teacher and the physical situation would not be such important variables. The number of aides and teachers in the room should be held to a constant ratio for all classrooms. Using a larger sample than this author was able to do would produce a better estimate of the population, as well as 
Tereasing the possibility of using the stronger and more complex parametric tests in the analysis of the results. 
ACKNOWLEDGEMENTS

For aid in the execution of this thesis, my sincere thanks are axpressed to my principal advisor, Dr. George T. Fitzelle for his Dderstanding assistance, to Dr. Elizabeth E. Page for her support, to Mr. Chris P. Tsokos for invaluable help with the statistical analysis, to Dr. Anna Guyette for aid in the initial stages, as well as the assistance of Dr. William J. Hemmerle, director of the Computer Laboratory.

The cooperation of the staff of the Carter Day Nursery, Nickerson House, Salvation Army Day Nursery, and the Warwick Community Action Nursery School was very much appreciated, thus enabling the author to secure the data for this study. 


\section{BIBLIOGRAPHY}

Masubel, David and Pearl Ausubel, "Ego Development Among Segregated Negro Children," Education in Depressed Areas, (ed.), A. H. Passow, New York: Teachers College, Columbia University Press, 1963, 109-141.

Bayley, Nancy, "Mental and Motor Development from Two to Twelve Years," Review of Educational Research, 1939, 9, 18-37.

Drnstein, Basil, "Language and Social Class," British Journal of ociology, 1960, 11, 271-276.

Bowlby, J., Maternal Care and Mental Health, Geneva: World Health Organization, 1952.

Chambers, Juanita, "Maternal Deprivation and the Concept of Time," American Journal of Orthopsychiatry, 1961, 31, 406-419.

Dennis, Nayne, "Causes of Retardation Among Institutional Children: Iran," Journal of Genetic Psychology, 1960, 96, 47-59.

Deutsch, Cynthia, "Auditory Discrimination and Learning: Social Factors," Merrill-Palmer Quarterly, 1964, 10, 277-296.

Deutsch, Martin, "The Disadvantaged Child and the Learning Process," Bducation in Depressed Areas, (ed.), A. H. Passow, New York: Meachers College, Columbia University Press, 1963, 163-179.

Dixon, Wilfred J. and F. J. Massey, Jr., Introduction to Statistical malysis, New York: McGraw-Hill, 1957.

Erikson, Erik, H., Childhood and Society, New York: Norton, 1963.

Wenichel, Otto, The Psychoanalytic Theory of Neurosis, New York: Norton, 1945.

Flavell, John H., The Developmental Psychology of Jean Piaget, New York: Van Norstrand, 1963.

Fryer, H. C., Concepts and Methods of Experimental Statistics, Boston: Allyn and Bacon, 1966.

Gewirtz, Jacob, "Factor Analysis of Some Attention-seeking Behaviors of Young Children," Child Development, 1956, 27(1), 17-36.

Gewirtz, Jacob, Donald Baer, and Chaya Roth, "A Note on Similar Effects of Low Social Availability of an Adult and Brief Social Deprivation in Young Children's Behavior," Child Development, 1958, 29, 149-152. 
Fartup, Willard W., and E. Duwayne Keller, "Nurturance in Pre-school

Children and Its Relation to Dependence," Child Development, 1960, $31,681-689$.

Hattwick, Berta W., "Interrelations Between Pre-school Child's Behavior and Certain Factors in the Home," Child Development, 1963, 7, 200226.

Hattwick, I. A., "Sex Differences in the Behavior of Nursery School Children," Child Development, 1937, 8, 343-355.

Heathers, G., "Emotional Dependence and Independence in Nursery School Play," Journal of Genetic Psychology, 1955, 87, 37-57.

Hunt, J. McV., "The Psychological Basis for Using Pre-school Enrichment as an Antidote for Cultural Deprivation," Merrill-Palmer Quarterly, $1964,10,209-248$.

Hunt, J. McV., Intelligence and Experience, New York: Ronald, 1961.

Mussen, Paul H., (ed.), Handbook of Research Methods in Child Development, New York: Wiley, 1960.

Office of Economic Opportunity, Headstart Child Development Programs, Community Action Program, Washington: Office of Economic Opportunity, 1966.

Parten, Mildred, "Social Participation Among Pre-school Children," Journal of Abnormal and Social Psychology, 1932, 27, 243-269.

Piaget, Jean, The Origins of Intelligence in Children, New York: Norton, 1963.

Piaget, Jean, Play, Dreams, and Imitation in Childhood, New York: Norton, 1963.

Plaget, Jean, "The Relations Between Intelligence and Affectivity in the Development of the Child," Bulletin of the Menninger Clinic, $1962,26,129-137$.

laget, Jean, The Child's Conception of Number, New York: Humanities, 1952.

laget, Jean, The Moral Judgment of the Child, London: Kegan Paul, 1932.

Plaget, Jean, The Child's Conception of Physical Causality, London: Kegan Paul, 1930.

Lessman, Frank, The Culturally Deprived Child, New York: Harper and Row, 1962. 
Sears, Robert R., J. W. M. Whiting, V. Nowlis, and Pauline Sears, "Some Child-rearing Antecedents of Aggression and Dependency in Young Children," Genetic Psychology Monographs, 1957, 47, 135-234.

Stith, Marjorie, and Ruth Connor, "Dependency and Helpfulness in Young Children," Child Development, 33, 1, 15-20.

Stendler, Celia B., "Critical Periods in Socialization and Overdependence," Child Development, 1952, 23, 3-12.

Tsokos, Chris P. Statistics 111, Course given at the University of Rhode Island, Kingston, R. I., Fall 1966.

Vebster's Collegiate Dictionary, Springfield: Merriam, 1947. 